\title{
Investigation of Ca and Mg Removal Capability of Cactus Powder from Hard Water
}

\author{
Tessema Derbe*, Hayelom Dargo, Worku Batu \\ Department of Chemistry, Adigrat University, Adigrat, Ethiopia \\ Email: ${ }^{*}$ benyamderbe@gmail.com
}

Received 30 August 2015; accepted 15 September 2015; published 21 September 2015

Copyright (C) 2015 by authors and OALib.

This work is licensed under the Creative Commons Attribution International License (CC BY). http://creativecommons.org/licenses/by/4.0/

(c) (i) Open Access

\section{Abstract}

Water that contains high amounts of Mg and Ca metals is hard water. The presence of these metal ions in water prevents the water from lather formation with soap. This leads to the consumption of large amounts of soaps which cause loss of economy. In light of the problem, this study is conducted to investigate the capability of cactus powder to remove $\mathrm{Mg}$ and Ca metals from hard water using FAAS. The result revealed that the concentration of both $\mathrm{Mg}$ and Ca metals decreased as the dose of cactus powder increased. The concentration of $\mathrm{Mg}$ was $5.965 \mathrm{ppm}$ in the absent of cactus powder, but it was $6.700 \mathrm{ppm}$ at $0.5 \mathrm{~g}, 2.967 \mathrm{ppm}$ at $1.5 \mathrm{~g}, 1.833 \mathrm{ppm}$ at $2.5 \mathrm{~g}, 2.200 \mathrm{ppm}$ at $3.5 \mathrm{~g}$ and $1.900 \mathrm{ppm}$ at $4.5 \mathrm{~g}$ of cactus powder. In parallel way, the concentration of Ca was $4.967 \mathrm{ppm}$ in the absent of cactus powder, but it decreased as $3.067 \mathrm{ppm}$ at $0.5 \mathrm{~g}, 1.667 \mathrm{ppm}$ at $1.5 \mathrm{~g}, 0.933 \mathrm{ppm}$ at $2.5 \mathrm{~g}, 0.967 \mathrm{ppm}$ at $3.5 \mathrm{~g}$ and $1.033 \mathrm{ppm}$ at $4.5 \mathrm{~g}$ with cactus powder. The percentage removal of both $\mathrm{Mg}$ and Ca metals from hard water increased as the dose of cactus powder increased. The percentage removal efficiency of cactus powder increased from $0.00 \%$ to $68.2 \%$ for Mg metal, and from $0.00 \%$ to $79.2 \%$ for Ca metal as the dose of cactus powder increased from $0.0 \mathrm{~g}$ to $4.5 \mathrm{~g}$, respectively. The percentage removal of Ca metal increased with contact time as $27.89 \%$ at $1 \mathrm{hr}$, $38.69 \%$ at $2 \mathrm{hr}, 53.27 \%$ at $3 \mathrm{hr}, 71.11 \%$ at $4 \mathrm{hr}$ and $71.53 \%$ at $5 \mathrm{hr}$. In the same way, the percentage removal of $\mathrm{Mg}$ metal increased with contact time as $16.00 \%$ at $1 \mathrm{hr}, 32.84 \%$ at $2 \mathrm{hr}, 48.00 \%$ at $3 \mathrm{hr}, 61.00 \%$ at $4 \mathrm{hr}$ and $57.00 \%$ at $5 \mathrm{hr}$. Thus, cactus powder has the capability to remove Ca and Mg metal ions from hard water due to the accessibility of its active sites.

\section{Keywords}

Hard Water, Cactus Powder, Magnesium and Calcium Metal

Subject Area: Analytical Chemistry

${ }^{*}$ Corresponding author. 


\section{Introduction}

\subsection{Background}

Hard water is not a health hazard, but dealing with hard water causing spot and brightness on cloth. Water that contains bicarbonates, chlorides and sulphates of calcium and magnesium metal is hard in nature [1]. Hardness of given water is a measure of the total concentration of $\mathrm{Ca}$ and $\mathrm{Mg}$ ions since dissolved calcium and magnesium are the two most common minerals that make the water "hard" [1] [2]. Hardness in water is not caused by a single substance but also by a variety of dissolved polyvalent metallic ions such as aluminium $\left(\mathrm{Al}^{3+}\right)$, barium $\left(\mathrm{Ba}^{2+}\right)$, manganese $\left(\mathrm{Mn}^{2+}\right)$, iron $\left(\mathrm{Fe}^{2+}\right)$ and zinc $\left(\mathrm{Zn}^{2+}\right)[1]-[3]$. But these ions typically make up only a very small fraction of total hardness [2].

\subsection{Sources of Hard Water}

The nature of hardness or softness of water varies from place to place. This reflects the nature of the geological properties of the area where the water has been contacted in [3]. The principal natural sources of hardness in water are the dissolved polyvalent metallic ions from sedimentary rocks, seepage and runoff from soils [4]. Calcium and magnesium are the two principal metal ions present in many sedimentary rocks such as limestone and chalk [1] [3]. They are also common essential mineral constituents of food [1]. As mentioned before, a minor contribution to the total hardness of water is also caused by other polyvalent ions, such as aluminum, barium, iron, manganese and zinc [1]. Therefore, hardness of given water is caused by many cationic and anionic species.

\subsection{Effect of Hard Water}

Hardness in drinking water is defined as those minerals dissolved in water having positive and negative electrical charges [2] [4] [5]. According to National Research Council (NRC) and World Health Organization (WHO) reports, hard water doesn't have health impacts [2]. But, the amount of hardness minerals in given water affects the amount of soap and detergent that is necessary for cleaning [4]. When hard water combines with soap, it gets a precipitate to form $\mathrm{Ca}$ and $\mathrm{Mg}$ salts [3] [5]. This prevents the formation lather with soap and it requires considerable amounts of soaps to produce lather [4] [6]. Hard water also produces a conspicuous deposit of precipitates such as insoluble metals, soaps or salts in containers, including "bathtub ring" [5].

Many people are facing challenges in the area of laundering and dishwashing of bathing and personal grooming [6]. They lose much time and many soaps to clean their cloths since soaps used in hard water combine with the minerals to form sticky soap curd [4]-[6]. This causes graying of white fabric on cloth and the loss of brightness in colors due to incomplete soil removal during laundry work [5].

Bathing with soaps in hard water causes a film of sticky soap curd on the skin which prevents soil and bacteria from being removed [3] [5]. This soap curd interferes with the return of skin to normal condition, is slightly acid in nature and may lead to irritation and itching of the skin [2]. Moreover, hard water causes soap curd on hair which makes the hair dull, lifeless and gray [1].

Besides, hard water also causes a film on glass shower doors, shower walls, bathtubs, sinks, faucets and dishes, which may be spotted when they dry [4] [6]. Furthermore, hard water deposits build in thickness that act as insulation, reducing the efficiency of heat transfer and conduction [3].

As described above, "hard water" contains high amounts of dissolved calcium and magnesium ions [1]-[3]. The presence or absence of these hardness minerals in drinking water is not known to pretend a health risk to users, rather poor soap and detergent performance in laundry [1].

Magnesium (Mg): It presents as exchangeable magnesium ion as cation-exchange complex and as solution in soluble $\mathrm{Mg}^{2+}$ ions [7]. $\mathrm{Mg}$ is used as a cofactor of many enzymes involved in carbohydrate and fat metabolism, protein synthesis, photosynthesis, and RNA and DNA synthesis [4] [7]. It is an active component of several enzyme systems in thymine pyrophosphate, and oxidative phosphorylation for activation of phosphate-transferring enzymes like myokinase, diphosphopyridine, nucleotide kinase and creatine kinase [6] [7]. It activates pyruvic acid carboxylase and pyruvic acid oxidase in the citric acid cycle [7]. It also acts as the main source of magnesium lactate which inhibits histidine decarboxylase and prevents the formation of histamine from the amino acid and histadine [7].

Excessive intakes of $\mathrm{Mg}$ lead to hypomagnesaemia while its deficiency enhances diabetes mellitus and ga- 
strointestinal tract abnormalities [2] [3] [5]. Drinking-water in which both magnesium and sulfate are present at high concentration can have a laxative effect [3] [5] [7]. Besides, high amounts of $\mathrm{Mg}$ in water prevent lather formation of water with soap. This leads to the use of high amounts of soap which causes loss of economy.

Calcium $(\boldsymbol{C a})$ : Calcium is a divalent alkaline earth metal and the 5th most plentiful element in the earth's crust [7]. It occurs in plant tissues as free $\mathrm{Ca}^{2+}$ and as combined form such as carboxylic, phosphorylic, phenolic hydroxyl groups, oxalates, carbonates and phosphates [2] [6]. It is essential to health in the osteoarticular system, in development and maintenance of the skeleton and in cardio-muscular systems [2] [7]. It is also used in blood coagulation, muscle contraction and nerve impulse transmission, in the conversion of prothrombin to thrombin and in milk clotting [7]. It is important to regulate blood pressure and kidney function and reduce blood cholesterol level [7].

A high calcium intake leads to urinary stone formation, rickets and osteoporosis; it inhibits the intestinal absorption of iron, zinc and other essential minerals [3] [7]. When calcium is absorbed in excess of need, the excess is excreted by the kidney in healthy people who do not have renal impairment [7]. Calcium interacts with iron, zinc, magnesium and phosphorus within the intestine, thereby reducing the absorption of these minerals. Moreover, the presence of high amounts of $\mathrm{Ca}$ ion in water also causes hard water [5] [7]. This hard water consumes high amounts of soaps and detergents in bathing and laundering.

Currently, many methods have been adopted to treat hard water like reverse osmosis, ion exchange and others, but these methods are costly and not available plentifully. Therefore, this study is designed to investigate the capability of cactus powder to remove $\mathrm{Ca}$ and $\mathrm{Mg}$ metals from hard water using Flame Atomic Absorption Spectrometer (FAAS).

\section{Methodology and Material}

\subsection{Description of Study Area}

The present study is conducted in Adigrat University, in northern region of Ethiopia. Adigratis a city and separate woreda that found in Tigray Region of Ethiopia. It is located in the eastern zone around $900 \mathrm{~km}$ far from Addis Ababa which is capital city of Ethiopia with longitude $14^{\circ} 16^{\prime} \mathrm{N} 39^{\circ} 27^{\prime} \mathrm{E}$ coordinates and latitude $14^{\circ} 16^{\prime} \mathrm{N}$ $39^{\circ} 27^{\prime} \mathrm{E}$ with an elevation of 2457 meters above sea level. Adigrat is endowed with cactus plant which is harvested once in a year. The largest pharmaceutical manufacturing plant in Ethiopia, "Addis Pharmaceuticals Factory SC", is also located in Adigrat.

\subsection{Equipment and Instruments}

Atomic absorption spectroscopy (buck scientific, model 210VGP FAAS) equipped with deuterium arc back ground correctors and hollow cathode lamps with air-acetylene flame was used for the investigation of $\mathrm{Ca}$ and $\mathrm{Mg}$ metals from hard water.

\subsection{Reagent and Chemical}

Stock standard solutions containing $1000 \mathrm{ppm}$ of the metals $\mathrm{Ca}$ and $\mathrm{Mg}$ were used for preparation of standards. Deionized water was used for rinsing of the glassware, sample bottles and for dilution of the sample solution.

\subsection{Collection of Plant Samples}

Mature healthy and fresh leaves of cactus were collected from side of Adigrat town. The collected leaves were washed with distilled water and the leaves were cut in to small pieces. The tip egged and their thick epidermis was removed. They were dried at $70^{\circ} \mathrm{C}-90^{\circ} \mathrm{C}$ in electric oven. The dried plant materials were ground into powder form using pestle and mortar.

\subsection{Procedure}

Four ppm of a known Concentration of Ca metal and six ppm of $\mathrm{Mg}$ were added into six $100 \mathrm{~mL}$ round flasks. Different dosages of cactus $(0.5,1.5,2.5,3.5,4.5 \mathrm{~g})$ were added and were filled with deionised water up to the mark of the flask. The solution in flasks were homogenized and allowed to settle for a few time. The absorbance was measured using FAAS. The absorbance was compared in the present and in the absent of cactus powder. 
The percentage removal (\%) of $\mathrm{Ca}$ and $\mathrm{Mg}$ metals by cactus was calculated using the equations [8]:

\%removal $=\frac{C_{i}-C_{f} \times 100}{C_{i}}$ where, $C_{i}$ and $C_{f}$ are the Concentrations of the $\mathrm{Ca}$ and $\mathrm{Mg}$ metals in the absent of cactus and in the present of cactus, respectively.

The percentage removal (\%) of $\mathrm{Ca}$ and $\mathrm{Mg}$ metals at various contact time was also calculated using as: $\%$ removal $=\frac{C_{t_{o}}-C_{t} \times 100}{C_{t_{o}}}$ where, $C_{t o}$ and $C_{t}$ are the Concentrations of the $\mathrm{Ca}$ and $\mathrm{Mg}$ metals at initial and final time, respectively.

\subsection{Statistical Analysis}

After the results were obtained and recorded, the mean, standard deviation, regression and correlation factors, Concentration and others were performed using data analysis packages such as Microsoft Excel 2007 and originlab 8.1. Mahts type software also uses to write mathematical equations. All measurements were done in triplicate and the results were reported as average values $\pm \mathrm{SD}$.

\section{Result and Discussion}

\subsection{Instrument Calibration}

The calibration curves were plotted as a function of absorbance versus Concentration of the standard solution. In this study two calibration curves were plotted for $\mathrm{Ca}$ and $\mathrm{Mg}$ metal as shown in Figure 1.

\subsection{Effect of Cactus Dosage on Removal of Ca and Mg Metal from Hard Water}

Calcium and magnesium ions are the main factor that contributes the hardness of water. These ions can form a precipitate with soap which is causing the buildup of soap scum [1]. This is due to the soap molecules are being precipitated by the $\mathrm{Ca}^{2+}$ and $\mathrm{Mg}^{2+}$ ions; there is less soap available to form lather [1]. This takes a considerable
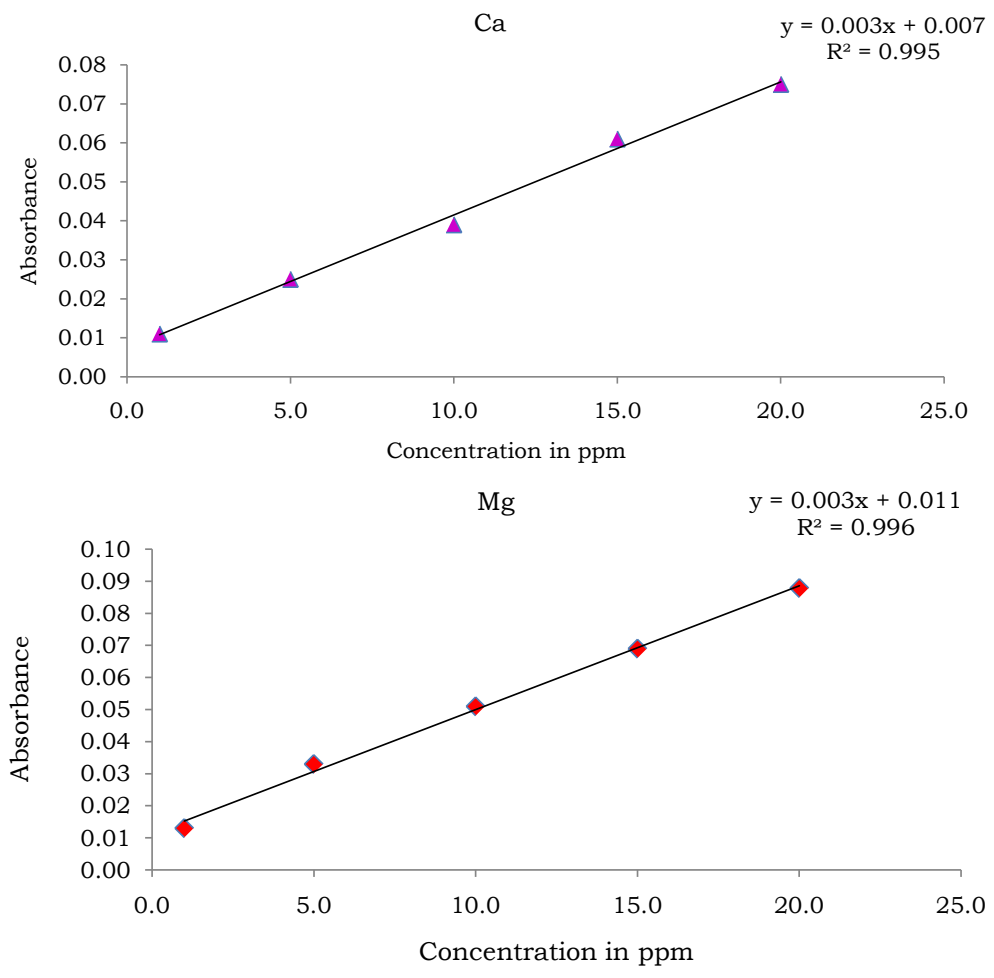

Figure 1. The calibration graphs of $\mathrm{Ca}$ and $\mathrm{Mg}$ metal standard solution. 
amount of soap to form lather which leads loss of economy and time. Besides, taking of a shower in hard water can be very frustrating and cause itching of skins [3] [5].

Additionally, hard water blocks boiler scale [2]-[4]. When hard water comes into contact with dissolved carbonates, a precipitate of insoluble calcium carbonate can form and build up on inside of water pipes which completely blocked the pipes [4]. By illumination the above impact of hard water, this study is focused to examine the hard water removal efficiency of cactus powder using FAAS.

As shown in Figure 2 and Table 1, the Concentration of Ca is decreased from $4.967 \mathrm{ppm}$ to $1.033 \mathrm{ppm}$ as the dose of cactus powder increased from $0.0 \mathrm{~g}$ to $4.5 \mathrm{~g}$. The Concentration of $\mathrm{Ca}$ metal from hard water decreased significantly from 4.967 to $0.933 \mathrm{ppm}$ as the dose of cactus powder increased from $0.0 \mathrm{~g}$ to $2.5 \mathrm{~g}$. But, the Concentration of $\mathrm{Ca}$ remains constant beyond $2.5 \mathrm{~g}$ dose of cactus powder. This is due to the fact that the equilibration of the active sites of cactus powder and the trapped Ca metal. In similar way, the Concentration of Mg metal is decreased from $5.965 \mathrm{ppm}$ to $1.90 \mathrm{ppm}$ as the dose of cactus powder increased from $0.0 \mathrm{~g}$ to $4.5 \mathrm{~g}$. But the slight increment (almost constant) value of the Concentration of $\mathrm{Mg}$ metal above $2.5 \mathrm{~g}$ of cactus powder is due to equilibration of the ambushed $\mathrm{Mg}$ metal in the active sites of cactus powder. This result reveals that, $2.5 \mathrm{~g}$ powder of cactus powder is enough to bind the $\mathrm{Mg}$ metal ion from the given hard water.

The Concentration of Mg metal increased $5.965 \mathrm{ppm}$ to $6.700 \mathrm{ppm}$ when $0.5 \mathrm{~g}$ of cactus powder is added. This might be due to the fact that, adding of a small amount of cactus dose $(0.5 \mathrm{~g})$ isn't sufficient to bind the metal ion from a given hard water since the cactus powder is dissolved in the hard water and in turn contribute the increment of $\mathrm{Mg}$ metal. Therefore, optimize dose of cactus powder is too important to remove $\mathrm{Ca}$ and $\mathrm{Mg}$ metal from hard water.

In general, the Concentration of both $\mathrm{Mg}$ and $\mathrm{Ca}$ metal are decreased as the dose of cactus is increased. The Concentration of $\mathrm{Mg}$ was $5.965 \mathrm{ppm}$ in the absent of cactus powder, but it is $6.700 \mathrm{ppm}$ at $0.5 \mathrm{~g}, 2.967 \mathrm{ppm}$ at $1.5 \mathrm{~g}, 1.833 \mathrm{ppm}$ at $2.5 \mathrm{~g}, 2.200 \mathrm{ppm}$ at $3.5 \mathrm{~g}$ and $1.900 \mathrm{ppm}$ at $4.5 \mathrm{~g}$ of cactus powder. The slight increment and almost constant Concentration of $\mathrm{Mg}$ metal exceeding $2.5 \mathrm{~g}$ cactus powder is due to the equilibration of $\mathrm{Mg}$ ion in the active sites of cactus powder. The other possible reason may be further addition of cactus powder beyond the optimum dose results re-dissociation of the trapped metal ions from the active sites of cactus powder.

In parallel way, the Concentration of Ca was $4.967 \mathrm{ppm}$ in the absent of cactus powder, $3.067 \mathrm{ppm}$ at $0.5 \mathrm{~g}$, $1.667 \mathrm{ppm}$ at $1.5 \mathrm{~g}, 0.933 \mathrm{ppm}$ at $2.5 \mathrm{~g}, 0.967 \mathrm{ppm}$ at $3.5 \mathrm{~g}$ and $1.033 \mathrm{ppm}$ at $4.5 \mathrm{~g}$ of cactus powder (Figure 2 and Table 1).

As it has been seen in Figure 3, the percentage removal of both $\mathrm{Mg}$ and $\mathrm{Ca}$ metal from hard water is increased as the dose of cactus powder increased. The hard water $(\mathrm{Mg})$ removal capability of cactus powder is increased from $0.00 \%$ to $68.2 \%$ as the cactus powder increased from $0.0 \mathrm{~g}$ to $4.5 \mathrm{~g}$. In the same way, the percentage removal of hard water $(\mathrm{Ca})$ is increased from $0.00 \%$ to $79.2 \%$ as the dose of cactus powder increased from $0.0 \mathrm{~g}$ to $4.5 \mathrm{~g}$. The slight decrement of percentage removal for both $\mathrm{Ca}$ and $\mathrm{Mg}$ metal beyond $2.5 \mathrm{~g}$ cactus powder might be due to the fact that re-dissociation of the trapped metal ions from hard water. The other probable reason may be the exhausting of the active site of cactus powder that will need to be regenerated continuously. Thus, in high adsorbent dose, the adsorption capacity is reduced due to overlapping of adsorption sites on adsorbent surface [1] [5].

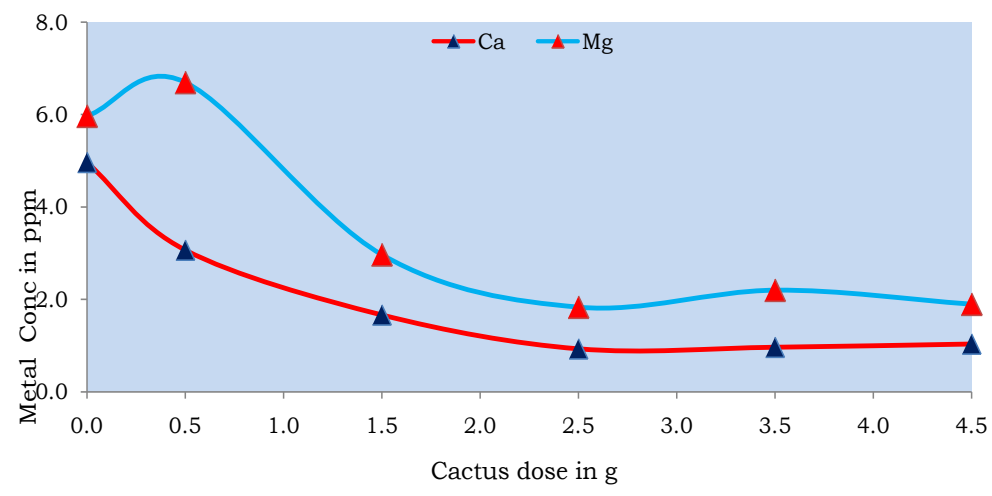

Figure 2. Effect of cactus dose on decrement of $\mathrm{Ca}$ and $\mathrm{Mg}$ metal from hard water at initial concentration of $4 \mathrm{ppm}$ and $6 \mathrm{ppm}$, respectively. 


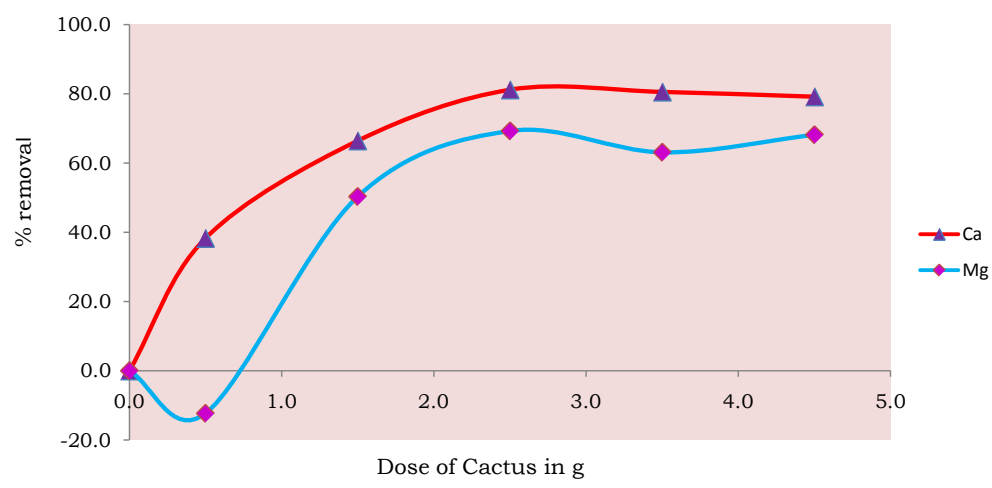

Figure 3. Percentage removal capability of cactus powder $\mathrm{Ca}$ and $\mathrm{Mg}$ metal from hard water treatment.

Table 1. Effects of cactus dose on removal of $\mathrm{Ca}(4 \mathrm{ppm})$ and $\mathrm{Mg}(6 \mathrm{ppm})$ metal from hard water.

\begin{tabular}{ccc}
\hline Cactus powder in gram & Concentration of Ca in ppm & Concentration of Mg in ppm \\
\hline 0.0 & $4.967 \pm 0.005$ & $5.965 \pm 0.012$ \\
0.5 & $3.067 \pm 0.013$ & $6.700 \pm 0.005$ \\
1.5 & $1.667 \pm 0.030$ & $2.967 \pm 0.01$ \\
2.5 & $0.933 \pm 0.001$ & $1.833 \pm 0.034$ \\
3.5 & $0.967 \pm 0.011$ & $2.200 \pm 0.010$ \\
4.5 & $1.033 \pm 0.023$ & $1.900 \pm 0.012$ \\
\hline
\end{tabular}

\subsection{Effect of Contact Time on Removal of Ca and Mg by Cactus Powder from Hard Water}

As it can be seen from Figure 4 and Table 2, the removal capability of cactus powder for $\mathrm{Ca}$ and $\mathrm{Mg}$ metal ions are increased with contact time. The effect of contact time on removal of $\mathrm{Ca}$ and $\mathrm{Mg}$ metal from hard water by cactus powder can be determined by phasing in different contact time. The percentage removal of Ca metal increased with contact time as $27.89 \%$ at $1 \mathrm{hr}, 38.69 \%$ at $2 \mathrm{hr}, 53.27 \%$ at $3 \mathrm{hr}, 71.11 \%$ at $4 \mathrm{hr}$ and $71.53 \%$ at $5 \mathrm{hr}$.

In the same way, the percentage removal of $\mathrm{Mg}$ metal increased with contact time as $16.00 \%$ at $1 \mathrm{hr}, 32.84 \%$ at $2 \mathrm{hr}, 48.00 \%$ at $3 \mathrm{hr}, 61.00 \%$ at $4 \mathrm{hr}$ and $57.00 \%$ at $5 \mathrm{hr}$. As the result indicates that the percentage removal of $\mathrm{Mg}$ metal is decreased slightly beyond $4 \mathrm{hr}$. This might be due to the re-dissociation of the trapped metal after end point of the adsorbed metal.

In general, the percentage removal of $\mathrm{Ca}$ and $\mathrm{Mg}$ metal ions from hard water is increased with contact time. This is the reason why as the contact time increased there is formation of stable complexes between the $\mathrm{Ca}$ and $\mathrm{Mg}$ metal ions with the active site of the cactus powder (Figure 4). Hence, the removal of $\mathrm{Ca}$ and $\mathrm{Mg}$ metal by cactus powder increased with the contact time (Figure 3 and Table 2).

Cactus powder has the capability to remove metal ions $(\mathrm{Ca}$ and $\mathrm{Mg}$ ) from hard water due to the accessibility of carboxyl, carbonyl and hydroxyl functional group as studied by various researchers Balaria and Schiewer $(2008,2009)$. Spectroscopic studies indicate the involvement of CO (carboxyl and carbonyl) and OH (hydroxyl) functional groups of the cactus powder leads in hydrogen bonding and donor-acceptor interactions between $\mathrm{Ca}$ and $\mathrm{Mg}$ metal ions to form coordinated compounds [9] [10]. Therefore, cactus powder has the capability to trap metal ions from hard water by it pore sites/ functional group (Figure 5).

As shown in Figure 5, cactus powder has ability to bind metal ions from hard water via it active sites. Hence, cactus is crucial in removing of metal ion from a given samples.

\section{Conclusion}

The result revealed that the concentration of both $\mathrm{Mg}$ and $\mathrm{Ca}$ metals decreased as the dose of cactus increased. The percentage removal of both $\mathrm{Mg}$ and $\mathrm{Ca}$ metals from hard water increased as the dose of cactus powder 


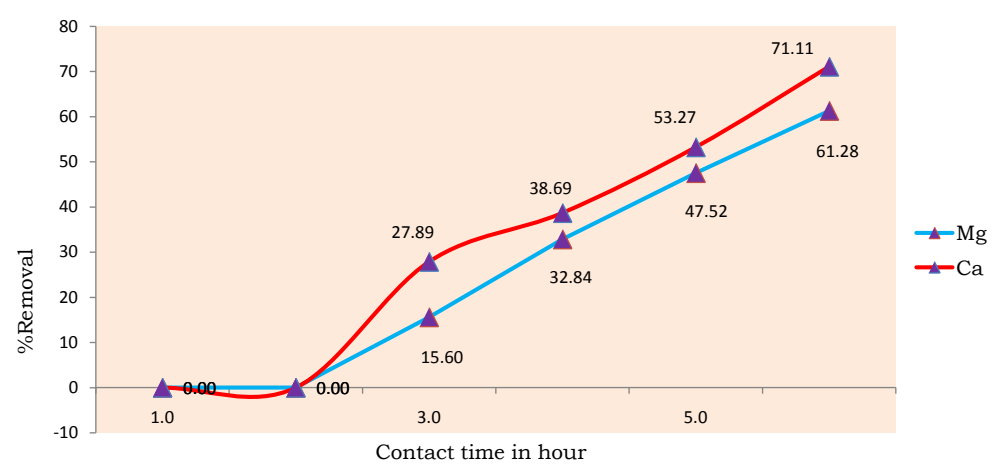

Figure 4. Effect of contact time on $\mathrm{Ca}$ and $\mathrm{Mg}$ ions removal using $2 \mathrm{~g}$ cactus powder at initial $4 \mathrm{ppm}$ of $\mathrm{Ca}$ and $\mathrm{Mg}$ at different time (hour).
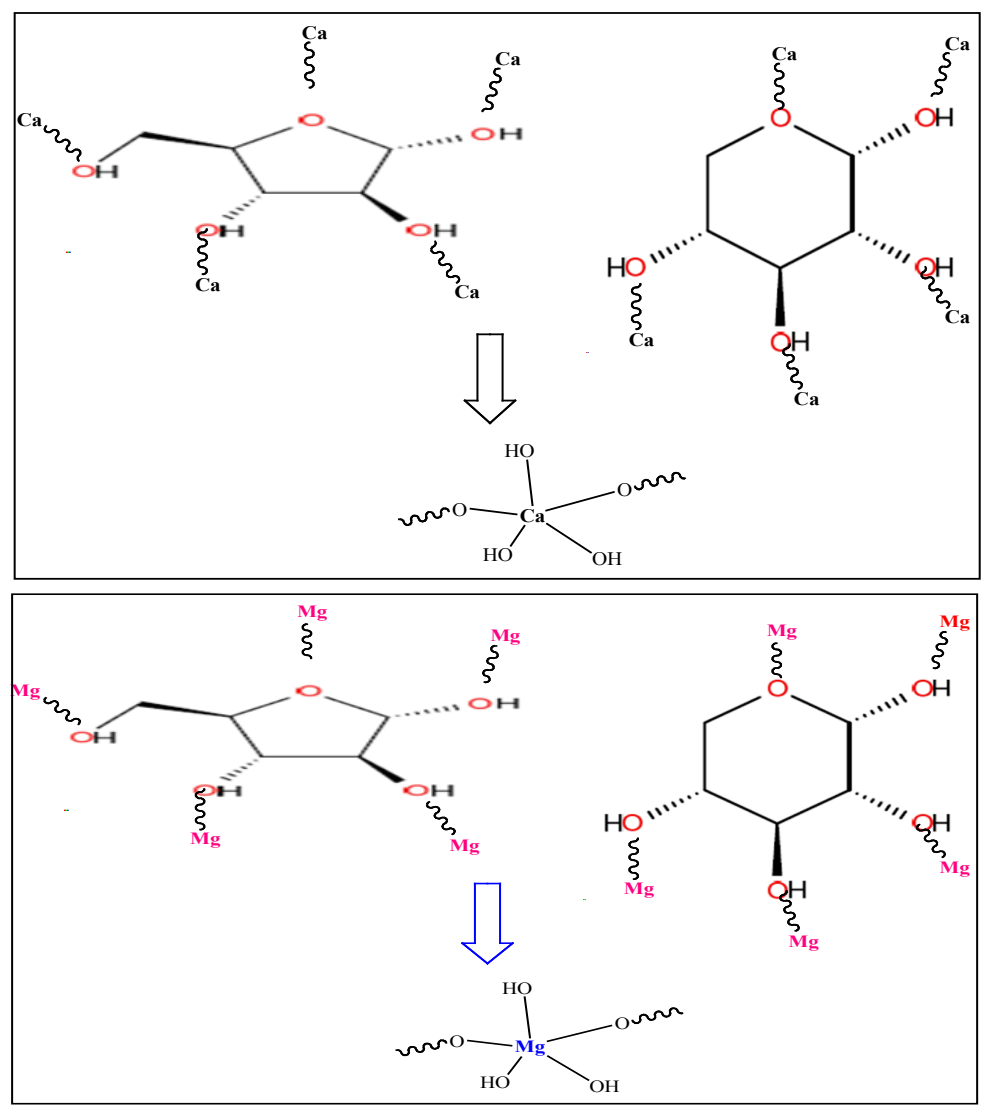

Figure 5. Mechanist trapping of $\mathrm{Ca}$ and $\mathrm{Mg}$ metals by cactus powder.

Table 2. Effects of contact on removal of $\mathrm{Ca}(4 \mathrm{ppm})$ and $\mathrm{Mg}(6 \mathrm{ppm})$ metal from hard water.

\begin{tabular}{rcccccc}
\hline Time & & $1 \mathrm{hr}$ & $2 \mathrm{hr}$ & $3 \mathrm{~h}$ & $4 \mathrm{hr}$ & $5 \mathrm{hr}$ \\
\hline \multirow{2}{*}{$\%$ removal } & $\mathrm{Ca}$ & $27.89 \%$ & $38.69 \%$ & $53.27 \%$ & $71.11 \%$ & $71.53 \%$ \\
& $\mathrm{Mg}$ & $16.00 \%$ & $32.84 \%$ & $48.00 \%$ & $61.00 \%$ & $57.00 \%$ \\
\hline
\end{tabular}

increased. The percentage removal of cactus powder increased from $0.00 \%$ to $68.2 \%$ for $\mathrm{Mg}$ and from $0.00 \%$ to $79.2 \%$ for $\mathrm{Ca}$ as the cactus powder increased from $0.0 \mathrm{~g}$ to $4.5 \mathrm{~g}$, respectively. The percentage removal of $\mathrm{Ca}$ and $\mathrm{Mg}$ ions from hard water increased with contact time. In general, cactus powder has the capability to re- 
move metal ions such as $\mathrm{Mg}^{2+}$ and $\mathrm{Ca}^{2+}$ from hard water. Thus, the removal ability of cactus powder increases with dose of cactus powder and contact time. Thus, this study invites the societies, researchers and people who work in launder to use cactus powder to relive the effect of hard water.

\section{Acknowledgements}

Researchers want to express their thanks to the college of Natural and computational science, department of chemistry, Arba Minch University and Mekelle University for providing laboratory facilities. They extend their pleasure to Adigrat University, Ethiopia, for financial supports for this study.

\section{References}

[1] Kumar, S.M., Gupta, O.P., Singh, D.K. and Prasad, A.S. (2014) Comparative Physico-Chemical Analysis of River Water and Underground Water in Winter Season of Rewa City, MP, India. International Journal of Environmental Science, 3, 59-61.

[2] Issa, J. and Babiker, O.A. (2013) Determination of Some Inorganic Constituents of Drinking Water in Zalingei Town Central Darfur State, Sudan. Journal of Science and Technology, 3, 1208-1214.

[3] Manjare, S.A., Vhanalakar, S.A. and Muley, D.V. (2010) Analysis of Water Quality Using Physico-Chemical Parameters Tamdalge Tank in Kolhapur District, Maharashtra. International Journal of Advanced Biotechnology and Research, 1, 115-119.

[4] Napacho, V. and Manyele, S.V. (2010) Quality Assessment of Drinking Water in Temeke District (Part II): Characterization of Chemical Parameters. African Journal of Environmental Science and Technology, 4, 775-789.

[5] Gyamfi, E.T., Ackah, M., Anim, A.K., Hanson J.K., Kpattah, L. and Enti-Brown, S. (2012) Chemical Analysis of Potable Water Samples from Selected Suburbs of Accra, Ghana. Proceedings of the International Academy of Ecology and Environmental Sciences, 2,118-127.

[6] Zuthi, M.F.R., Biswas, M. and Bahar, M.N. (2009) Assessment of Supply Water Quality in the Chittagong City of Bangladesh. Journal of Engineering and Applied Science, 4, 73-80.

[7] Derbe, T. and Yilma, B. (2015) Spectroscopic Investigation of Metal Level in Aloe Vera Plant, and the Soil Where the Aloe Vera Grows: Arba Minch, Southern Ethiopia. Modern Chemistry, 3, 1-8. http://dx.doi.org/10.11648/j.mc.20150301.11

[8] Alfarra, S.R., Ali, E.N. and Yusoff, M.M. (2014) Removal of Heavy Metals by Natural Adsorbent. International Journal of Bioscience, 4, 130-139.

[9] Fox, I.D. (2011) Cactus Mucilage-Assisted Heavy Metal Separation: Design and Implementation. Graduate School Theses and Dissertations, University of South Florida, Tampa, 1-149.

[10] Derbe, T., Dargo, H. and Batu, W. (2015) Cactus Potential in Heavy Metal (Pb and Cd) Removal in Water Sample Collected from Rural Area around Adigrat Town. Chemistry and Materials Research, 7, 84-92. 